\title{
Impact of high temperature on mortar mixes containing additives
}

\author{
Kiran Devi, Babita Saini* and Paratibha Aggarwal \\ Civil Engineering Department, National Institute of Technology, Kurukshetra-136119, India \\ * Corresponding Author: babitasaini6@gmail.com
}

Submitted :07/05/2020

Revised :20/03/2021

Accepted : 28/03/2021

\begin{abstract}
The structures may be exposed to fire or high temperature conditionally or accidentally. Alteration in the behavior of concrete structure is prospective under the exposure of elevated temperature. There is an urge to find the materials that can resist the alteration in physiochemical and strength properties of cementitious materials under high temperature. In the present study, the effect of elevated temperature on cement mortar consisting of additives, i.e., accelerating admixtures, and stone waste, i.e., stone slurry powder, was investigated and compared with specimens at room temperature. The aim of the study was to examine the practicability of these additives under exposure to high temperatures. The mortar specimens were exposed to various temperatures, i.e., $150^{\circ} \mathrm{C}, 300^{\circ} \mathrm{C}, 450^{\circ} \mathrm{C}$, and $600^{\circ} \mathrm{C}$, for the duration of one hour and compared with unheated samples. The change in mass, strength, and micro-structure of mortar specimens at elevated temperature was studied. The environmental assessment and performance evaluation of various mortar mixes were also evaluated. The mass of mortar specimens reduced as the exposure temperature of specimens was raised. The residual strength of mortar increased up to a certain temperature; afterwards, it decreased. Stone slurry powder and calcium nitrate can be used individually and in combination to resist thermal changes.
\end{abstract}

Keywords: Accelerators; Environmental assessment; Microstructural analysis; Stone slurry powder; Strength and mass loss.

\section{INTRODUCTION}

Fire safety of structure is a crucial aspect due to numerous terrorist attacks, war operations, and natural disasters caused by industrial production and traffic accidents. Fire jeopardizes human health, wildlife, personal, public property, and environmental damage (Bodnarova et al., 2017). The cement composites are prone to high temperature either during fire or vicinity of furnace and reactors. The behavior of cement-based materials is related to the properties and compositions of used ingredients under exposure to higher temperature. The strength and durability of cement composites significantly decrease under exposure to high temperature due to the formation of cracks and spalling, ultimately leading to deterioration and sometimes even failure of the structure. The physical structure and chemical compositions of cement composites alter under the exposure to elevated temperature (Arioz, 2007, Bing”ol and G"ul, 2009, Karahan, 2011, Shaikh and Taweel, 2015, Hager et al., 2016 \& Belouadah et al., 2018). The color, strength, density, elastic modulus, and appearance of concrete structures changed under the exposure to high temperature, which results in reduction in the quality of concrete (Demirel and Kelestemur, 2010, Netinger et al., 2011, Aslani and Samali, 2014 \& Baloch et al., 2018). The degradation in mechanical properties can be attributed to 
physical, thermal, and chemical changes in the hydration product of cement paste and aggregates (Guerrieri et al., 2009). The advantage of concrete using as a construction material is to have significant resistance against elevated temperature. The distress in concrete occurs in the form of cracking and spalling on its surface when subjected to elevated temperatures. The introduction of industrial by-products influenced the structural properties of concrete (T"urkmen and Findik, 2013 \& Khan and Abbas, 2016). The physical and chemical changes due to elevated temperature affect the strength and durability of concrete. The consequence of high temperature on mechanical and durability properties had been investigated by researchers to develop the fire-resistant materials. The properties of cement paste, aggregates, cement paste aggregate bonding, presence of supplementary cementitious materials, heating rate, cooling type, loading conditions, and moisture regime were found dominating factors that influenced the fire resistance of concrete (Koksal et al., 2015). High temperature affects the structure of a building; therefore, it needs to select suitable materials and specific compositions that are important (Melichar et al., 2017).

During dimensioning of stones, a large amount of waste in various forms is generated at sites. The waste is directly disposed off to the surrounding area or in streams. The disposal of stone waste on land reduces the fertility of soil by clogging the water percolation due to the presence of its finer particles. The lifting of fine particles of stone slurry by air on drying is injurious to health and also causes environmental issues. The direct disposal of stone waste into water courses pollutes the water. The sustainable solution to disposal problem of stone waste is to utilize it in the construction industry as a substitution to cementitious materials. Therefore, utilization of stone powder and other industrial by-products in cement based materials helps produce environment friendly end products with conservation of natural resources, reduction of landfill issues, and development of sustainable materials (Rana et al., 2015, Thaarrini and Ramasamy, 2016, Singh et al., 2017, Khaliq and Taimur, 2018, Sánchez et al., 2018 \& Devi et al., 2018b; 2019).

Concrete is the important building materials in this modern building techniques (Güçlüer, 2021). Admixtures are the chemicals used either before or during the blending of ingredients to modify the specific characteristics of cementitious materials. The chemical admixtures are air entrainer, accelerators, water reducer, and retarder types and have their applications. Accelerating admixtures accelerate the stiffening and early age strength of mortar and concrete. The most commonly used accelerating admixture is calcium chloride, which is not used in reinforced structures because of its corrosive behavior. Non-chloride accelerating admixtures have also been used in concrete to avoid corrosive situations. Calcium nitrate $(\mathrm{CN})$ and triethanolamine (TEA) have been used in the present work (Aggoun et al., 2008, Devi et al., 2018a \& Devi et al., 2020).

The weight and relative strength of specimens reduced with temperatures. The influence of high temperature on the strength of concrete with river gravel aggregates was more pronounced (Arioz, 2007). The addition of steel fiber in mortar limits the damage and cracking when subjected to high temperature; polypropylene fiber created porosity and limited the pore pressure, consequently reducing the cracking (Ezziane et al., 2011). The pore area fraction increased, and hydrated paste area fraction decreased with a rise in temperature, which resulted in the degradation of microstructure and the affected strength of the mortar. The critical temperature for the change in properties of mortar specimens containing fly ash and metakaolin was $400^{\circ} \mathrm{C}$ (Nadeem et al., 2013). The loss in strength properties of normal strength high-performance concrete due to elevated temperature was similar to high strength highperformance concrete. Concrete with fiber increased the residual strength. The explosive spalling was prevented by polypropylene fiber (Peng et al., 2014). The lightweight concrete with vermiculite had good performance at a higher temperature (Koksal et al., 2015). The inclusion of limestone powder (LP) reduced the creep of the concrete at a higher temperature, and this reduction increased at the higher replacement of cement by limestone powder. The variation of internal relative humidity was delayed by LP for all the mix proportions (Wang et al., 2015). The silica fume (SF) based concrete had poor performance, while slag-based concrete showed good performance against the high temperature (Khan and Abbas, 2016). Crushed rock dust as filler materials improved the internal microstructure. The microstructure was still dense, and fewer micropores were present at $200^{\circ} \mathrm{C}$, and little deterioration of 
microstructure bonding was observed at $400^{\circ} \mathrm{C}$ temperature. The significant damage takes place at $600^{\circ} \mathrm{C}$ temperature due to enlarged cracks (Kumar and Ram, 2019). The cement matrix consisting of calcined diatomite powder was compact, and bonding between cement paste and sand was intact at ambient temperature. At $400^{\circ} \mathrm{C}$ temperature, cement matrix was still compact and strong but weakened the interface zone between cement paste and sand. After $800^{\circ} \mathrm{C}$, critical changes in the morphology of $\mathrm{CSH}$ were observed, and they weakened the bonding at $1000^{\circ} \mathrm{C}$ (Saridemir et al., 2020). The alkali-activated mortar with waste ceramic powder (WCP) at $70 \%$ showed more stable surface at high temperatures than at 50\% WCP (Shah and Huseien, 2020). The ettringite and monosulphate phase decomposed, and it was absent at $300^{\circ} \mathrm{C}$ temperature. At $550^{\circ} \mathrm{C}$ and $900^{\circ} \mathrm{C}$, dense structure of hydration products becomes gradually destroyed and loose (Lin et al., 2020). A simplified relationship between external restraint degree and allowed tenmperature difference was developed (Xin et al., 2018)

\section{Research Significance}

In the present work, admixtures, i.e., calcium nitrate $(\mathrm{CN})$ and triethanolamine (TEA) as additive of accelerating nature, and stone slurry powder (SSP), waste from stone industries (replacement of cement), have been used in cement mortar to study its behavior at elevated temperature. Residual strength of specimens was defined as strength measured after cooling the specimens. The influence of high temperatures $\left(150^{\circ} \mathrm{C}, 300^{\circ} \mathrm{C}, 450^{\circ} \mathrm{C}\right.$, and $\left.600^{\circ} \mathrm{C}\right)$ with an exposure duration of 60 minutes on cement mortar consisting of additives in terms of variation in mass, strength, and microstructural characterization was investigated. The ecological and economic analysis was also carried out. The purpose was to check the feasibility of these materials individually and in combination with mortar at high temperatures. The aim of combining admixtures and SSP in cement mortar was to make cost-effective and ecofriendly construction materials that can also resist the changes under elevated temperature effectively.

\section{EXPERIMENTAL PROGRAM}

\section{Materials and Mix Proportions}

To study the behavior of cement mortar consisting of triethanolamine, calcium nitrate, and stone slurry powder under exposure to elevated temperature, twenty-two mortar mixes of different mix proportions were prepared. Ordinary Portland cement (OPC) of 43 grade (fineness of 4\%, 27.5\% consistency, specific gravity of 3.12, and 28 days strength of $44.5 \mathrm{MPa}$ ) conforming to Indian Standard (IS): 8112-1989 and coarse sand (fineness modulus of 3.17, zone II, specific gravity 2.62) conforming to IS: 383-2016 were used to study the consequence of elevated temperature on mass and residual strength of cement mortar (Devi et al., 2018). The cement mortar was prepared in accordance with IS: 4031-1989 (Part-6). Tap water was used during the whole experimentation. Stone slurry powder (white in color and specific gravity 2.72), waste generated during dimensioning of stones, was used as a partial substitution to cement. SSP was procured from Kota stone (calcareous sedimentary rock), Kota, Rajasthan, India, in slurry form, dried under sunlight and crushed to fine particles, and utilized as replacement of cement. Accelerators, i.e., calcium nitrate tetra-hydrate purified $\left[\mathrm{Ca}\left(\mathrm{NO}_{3}\right)_{2} \cdot 4 \mathrm{H}_{2} \mathrm{O}\right]$ and triethanolamine $\mathrm{LR}$ having the chemical formula $\left[\mathrm{C}_{6} \mathrm{H}_{15} \mathrm{NO}_{3}\right]$, were used as cement additives in the mortar and procured from the local supplier (Devi et al., $2019 \mathrm{~b}$ and Devi et al., 2020).

Table 1. Chemical composition of OPC and SSP (Devi et al., 2020).

\begin{tabular}{|c|c|c|c|c|c|c|c|}
\hline Chemical composition (\%) & $\mathrm{CaO}$ & $\mathrm{SiO}_{2}$ & $\mathrm{Al}_{2} \mathrm{O}_{3}$ & $\mathrm{MgO}$ & $\mathrm{Na}_{2} \mathrm{O}$ & $\mathrm{FeO}$ & $\mathrm{K}_{2} \mathrm{O}$ \\
\hline OPC & 60.29 & 21.42 & 5.91 & 2.65 & 0.64 & 4.81 & 1.11 \\
\hline SSP & 49.78 & 17.01 & 2.92 & 0.61 & 0.88 & 0.14 & 0.42 \\
\hline
\end{tabular}


The chemical composition of OPC and SSP from energy dispersive X-ray spectroscopy (EDS) has been tabulated in Table 1, and their scanning electron microscopy (SEM) and EDS images have been illustrated in Figures 1 (a), (b), (c), and (d), respectively. The particle size of SSP was finer as compared to cement as observed from SEM micrographs. The irregular shape of SSP particles was also observed from SEM image. EDS images showed the presence of elements, i.e., calcium, silica, aluminum, iron, sodium, etc. From EDS analysis, it was observed from the chemical composition of cement and SSP that they were quite similar. With calcium being a major element, SSP was calcite in nature, contributing to binding capabilities by reacting with tricalcium aluminate $\left(\mathrm{C}_{3} \mathrm{~A}\right)$ to form calcium carbon aluminate.

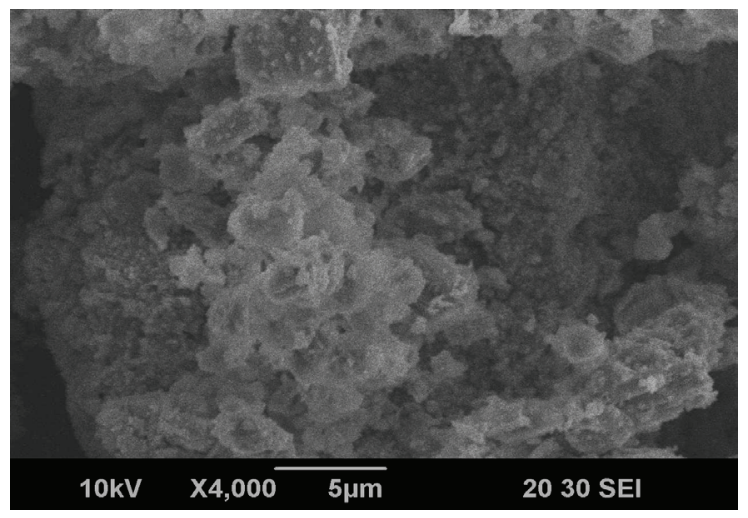

(a)

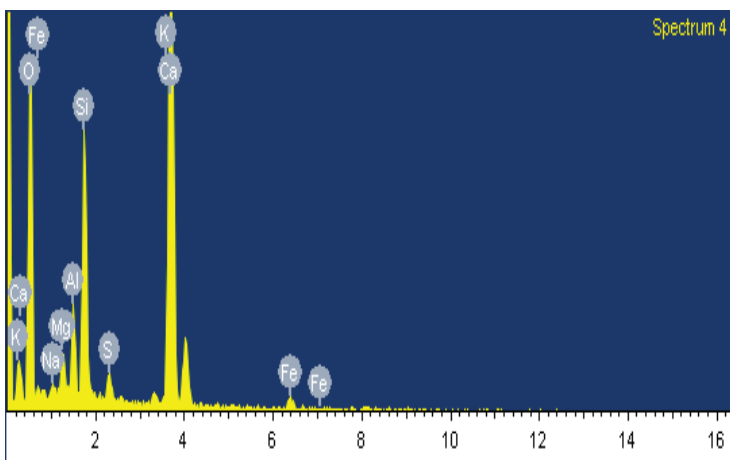

Full Scale 368 cts Cursor: 0.000

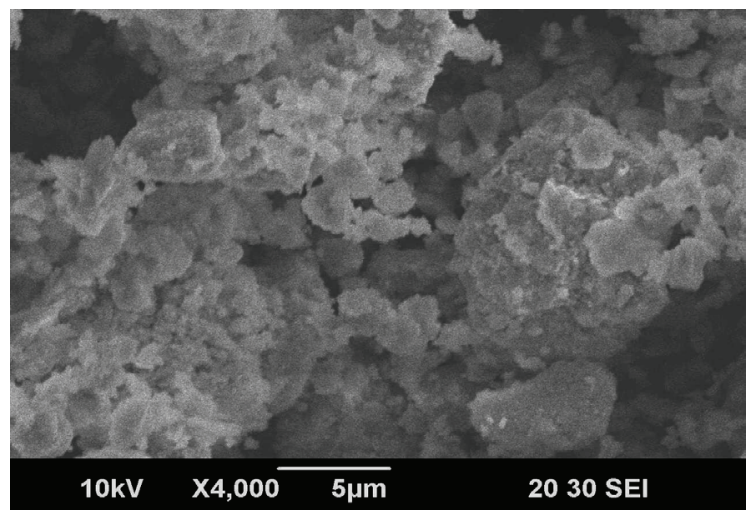

(b)

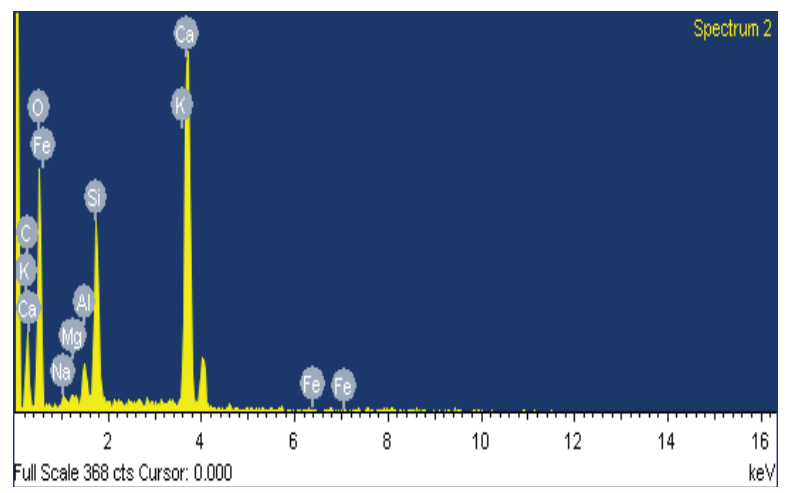

(d)

Figure 1. (a) SEM of PC; (b) SEM of SSP; (c) EDS of PC; (d) EDS of SSP.

\section{Mixture Proportions}

$\mathrm{CN}(0 \%, 1 \%$ and $2 \%)$, TEA $(0 \%, 0.025 \%, 0.050 \%$, and $0.1 \%)$, and SSP $(0 \%, 2.5 \%, 5 \%, 7.5 \%$, and $10 \%)$ have been used in mortar mixes, and twenty-two various mixes of mortar were studied as tabulated in Table 2 . The quantity of cement, sand, and water was $575 \mathrm{~kg} / \mathrm{m}^{3}, 1725 \mathrm{~kg} / \mathrm{m}^{3}$, and $158.25 \mathrm{~kg} / \mathrm{m}^{3}$, and quantities of CN, TEA, and SSP were varied according to the dosages. The water-binder ratio was kept constant at 0.275 , and cement-sand ratio was $1: 3$ throughout the experimentation. 
Table 2. Mix proportions of various mixes of cement mortar (w/b .275).

\begin{tabular}{|c|c|c|c|c|c|c|}
\hline Mix No. & Cement, $\mathrm{kg} / \mathrm{m}^{3}$ & Sand, $\mathrm{kg} / \mathrm{m}^{3}$ & water, $\mathrm{kg} / \mathrm{m}^{3}$ & $\mathrm{SSP}, \mathrm{kg} / \mathrm{m}^{3}$ & $\mathrm{CN}, \mathrm{kg} / \mathrm{m}^{3}$ & TEA, $\mathrm{kg} / \mathrm{m}^{3}$ \\
\hline F0 & 575 & 1725 & 158.1 & 0 & 0 & 0 \\
\hline $\mathrm{F} 1$ & 560.62 & 1725 & 158.1 & 14.73 & 0 & 0 \\
\hline $\mathrm{F} 2$ & 546.25 & 1725 & 158.1 & 28.75 & 0 & 0 \\
\hline F3 & 531.88 & 1725 & 158.1 & 43.13 & 0 & 0 \\
\hline F4 & 517.5 & 1725 & 158.1 & 57.5 & 0 & 0 \\
\hline F5 & 575 & 1725 & 158.1 & 0 & 0 & 0.14 \\
\hline F6 & 575 & 1725 & 158.1 & 0 & 0 & 0.29 \\
\hline F7 & 575 & 1725 & 158.1 & 0 & 0 & 0.58 \\
\hline F8 & 575 & 1725 & 158.1 & 0 & 5.75 & 0 \\
\hline F9 & 575 & 1725 & 158.1 & 0 & 11.5 & 0 \\
\hline F10 & 575 & 1725 & 158.1 & 0 & 5.75 & 0.14 \\
\hline F11 & 575 & 1725 & 158.1 & 0 & 11.5 & 0.14 \\
\hline F12 & 546.25 & 1725 & 158.1 & 28.75 & 0 & 0.29 \\
\hline F13 & 531.88 & 1725 & 158.1 & 43.13 & 0 & 0.58 \\
\hline F14 & 546.25 & 1725 & 158.1 & 28.75 & 5.75 & 0 \\
\hline F15 & 531.88 & 1725 & 158.1 & 43.13 & 5.75 & 0 \\
\hline F16 & 546.25 & 1725 & 158.1 & 28.75 & 11.5 & 0 \\
\hline F17 & 531.88 & 1725 & 158.1 & 43.13 & 11.5 & 0 \\
\hline F18 & 546.25 & 1725 & 158.1 & 28.75 & 5.75 & 0.58 \\
\hline F19 & 531.88 & 1725 & 158.1 & 43.13 & 5.75 & 0.58 \\
\hline F20 & 546.25 & 1725 & 158.1 & 28.75 & 11.5 & 0.29 \\
\hline $\mathrm{F} 21$ & 531.88 & 1725 & 158.1 & 43.13 & 11.5 & 0.29 \\
\hline
\end{tabular}

\section{Methods}

The cement mortar cubes were used to investigate the impact of elevated temperature on mass, residual strength, and microstructure. The cement mortar cubes of standard size of $70.6 \mathrm{~mm} \times 70.6 \mathrm{~mm} \times 70.6 \mathrm{~mm}$ were prepared as per IS: 4031-1988 (Part-6). After completing 28 days of water curing, mortar specimens were withdrawn, dried, and then held in an electric furnace for required temperatures for 60 minutes; after turning off the furnace, specimens were annealed until the room temperature attained. After cooling, mass and strength of the specimens were measured (Koksal et al., 2015; Cheyrezy et al., 2001 \& Netinger et al., 2011). Initially, mortar specimens were exposed to higher temperature $900-1000^{\circ} \mathrm{C}$ (after literature review), but the specimens burst at high temperatures; thereby, 
temperature was restricted to $600^{\circ} \mathrm{C}$ after trials. To examine the effect of temperatures, temperature from room temperature to $600^{\circ} \mathrm{C}$, four intervals of temperatures were selected. The temperature variation was $150^{\circ} \mathrm{C}, 300^{\circ} \mathrm{C}$, $450^{\circ} \mathrm{C}$, and $600^{\circ} \mathrm{C}$, and the rate of heating was kept $100^{\circ} \mathrm{C} / \mathrm{hr}$ in the furnace. The residual strength of mortar at different temperatures was compared with the unheated mortar specimens. The mass loss of specimens was determined by the following equation:

Massloss $=\frac{\left(W_{1}-W_{2}\right)}{W_{1}} \times 100$

where $\mathrm{W}_{1}=$ initial weight of mortar specimen; $\mathrm{W}_{2}=$ weight of specimen after exposure to elevated temperature.

\section{Ecological and Economical Analysis of Mortar}

In the construction industry, cement is the main ingredient of concrete, which is responsible for the emission of $\mathrm{CO}_{2}$ after coarse aggregates and fine aggregates. Coarse aggregates have a higher contribution in releasing $\mathrm{CO}_{2}$ during all processing than fine aggregates, because the former are crushed not graded. Flower and Sanjayan (2007) suggested that emission due to chemical admixtures is neglected due to very small quantity as compared to other ingredients; but in this study, their effects are considered except TEA, because its dosage is very low $\left(<21 / \mathrm{m}^{3}\right)$. Also, batching, transportation, and placing of concrete have less contribution to $\mathrm{CO}_{2}$ emission (Long et al., 2017). Since the use of cement leads to harass the environment, therefore, it needs a replacement partially or fully with suitable industrial by-products to conserve the natural resources and emission of greenhouse gases. This small step leads to the development of sustainable construction. The ecological and economic aspects are two factors that can be used to assess sustainability. The ecological aspect of mortar and concrete can be analyzed in terms of embodied energy (EE) and embodied carbon dioxide $\left(\mathrm{ECO}_{2}\right)$, and economic analysis can be analyzed in terms of cost. $\mathrm{EE}$ and $\mathrm{ECO}_{2}$ are defined as the consumption of energy and emission of $\mathrm{CO}_{2}$ during the assembly, transportation, installation, and disassembly of a material/product. The values for $\mathrm{EE}$ and $\mathrm{ECO}_{2}$ for cement, sand, coarse aggregates, water, $\mathrm{CN}$, TEA, and SSP have been taken from the literature (Gupta et al., 2019 \& Siddque et al., 2019) and have been given in table 3.

Table 3. $\mathrm{EE}, \mathrm{ECO}_{2}$, and cost of raw materials.

\begin{tabular}{|c|c|c|c|c|c|c|c|}
\hline Materials & Cement & Sand & $\begin{array}{c}\text { Coarse } \\
\text { aggregates }\end{array}$ & Water & CN & TEA & SSP \\
\hline $\mathrm{EE}, \mathrm{MJ} / \mathrm{kg}$ & 4.8 & 0.081 & 0.0083 & 0.2 & 0.1368 & - & - \\
\hline $\begin{array}{c}\mathrm{ECO} 2, \\
\mathrm{kgCO}_{2} / \mathrm{kg}\end{array}$ & 0.93 & 0.0051 & 0.0008 & 0.0008 & 0.481 & - & - \\
\hline $\mathrm{Cost}, \mathrm{USD}$ & 0.084 & 0.014 & 0.025 & 0.0007 & 5.92 & 14.59 & - \\
\hline
\end{tabular}

Note that emission and cost related to the transportation of raw materials and production of mortar have not been considered. The price of materials was taken as market values of Kurukshetra, India, only. These values are used to calculate the value of $\mathrm{EE}, \mathrm{ECO}_{2}$, and cost of mortar by using the following equation: 
$E E / E C O_{2} / C o s t=\Sigma g_{i} m_{i}$

where $\mathrm{g}_{\mathrm{i}}=\mathrm{EE}$ per unit mass of materials and mi indicate the mass of mortar ingredients i per unit cubic meter.

\section{Performance Evaluation}

The quantitative analysis can be used to describe the performance of additives in mortar rather than qualitative terms. If the performance of plain mortar mix is considered as 1.0, then the performance of mortar with additives will be less than or greater than 1, which signifies the inferior or superior performance with reference to plain mix, respectively, in different aspects. The performance of additives, i.e., SSP, CN, and TEA, individually, will be evaluated with respect to plain mortar mix (Kayali and Ahmed, 2013)

\subsection{Micro-Structure Analysis}

The selected mix proportions were selected to study the microstructural properties of cement mortar containing CN, TEA, and SSP at temperatures, i.e., room temperature and $300^{\circ} \mathrm{C}$. The fractured samples of selected mortar cubes have been collected after strength test, and SEM analyses were conducted.

\section{RESULTS AND DISCUSSION}

\section{Change in Mass}

The effect of high temperature on mass loss of mortar has been studied and shown in Figures 2 (a) and (b). The mortar specimens were exposed to room temperature, $150^{\circ} \mathrm{C}, 300^{\circ} \mathrm{C}, 450^{\circ} \mathrm{C}$, and $600^{\circ} \mathrm{C}$, for the duration of 60 minutes to study their impact on mass of mortar. A significant loss in mass was observed as the temperature was raised. The mass loss varied from $1.93 \%$ to $4.68 \%, 3.59 \%$ to $7.18 \%, 5.28 \%$ to $8.4 \%$, and $6.59 \%$ to $8.94 \%$, respectively, at $150^{\circ} \mathrm{C}$, $300^{\circ} \mathrm{C}, 450^{\circ} \mathrm{C}$, and $600^{\circ} \mathrm{C}$ temperatures, respectively. Mixes F4 and F21 had the maximum and minimum mass loss at all the temperatures, as observed from Figure 2 (a). The mass loss of all the mix proportions increased with the temperature. The enhancement in mass loss of stone slurry powder may be attributed to the increase of voids in concrete (Khan and Abbas 2016). The reduction in mass may be attributed to the evaporation of water from cement paste and the formation of air voids (Demirel and Kelestemur 2010). The mass loss reduced with temperature due to release of physical or chemical bound water in mortar specimens consisting of SSP. After $450^{\circ} \mathrm{C}$ temperature, mass losses were due to vaporization of capillary water followed by runoff adsorbed and inter layer water. The mass loss occurred predominantly at $300-450^{\circ} \mathrm{C}$; afterwards, it occurred at slow rate. The mass loss of heated specimen occurred due to eviction of hydrated water from hardened cement matrix and formed air voids in the concrete. The reduction in mass of mortar specimens confirmed the deterioration of structural integrity. The mass loss in mortar specimens below $450^{\circ} \mathrm{C}$ temperature may be due to evaporation of free water and capillary water. Above $450^{\circ} \mathrm{C}$ temperature, decomposition of $\mathrm{CSH}$ gel takes place, and hydrated water in $\mathrm{CSH}$ gel release results in mass loss of mortar samples (Kumar and Ram, 2019; Saridemir et al., 2020).

Figure 2 (b) showed the percentage variation of mass loss of cement mortar with reference to plain mix. Addition of CN, SSP, and TEA increased the mass loss as compared to plain mix at all high temperatures and also increased with the rise in temperature except for combination of additional materials at $150^{\circ} \mathrm{C}$ temperature. Addition of $\mathrm{CN}$ $(1 \%)$ increased the mass loss $9.6 \%, 41 \%, 24 \%$, and $8 \%$ at $150^{\circ} \mathrm{C}, 300^{\circ} \mathrm{C}, 450^{\circ} \mathrm{C}$, and $600^{\circ} \mathrm{C}$, respectively, and $\mathrm{CN}$ $(2 \%)$ increased the mass loss by $5 \%, 26 \%, 18 \%$, and $6 \%$ at $1500^{\circ} \mathrm{C}, 300^{\circ} \mathrm{C}, 450^{\circ} \mathrm{C}$, and $600^{\circ} \mathrm{C}$, 


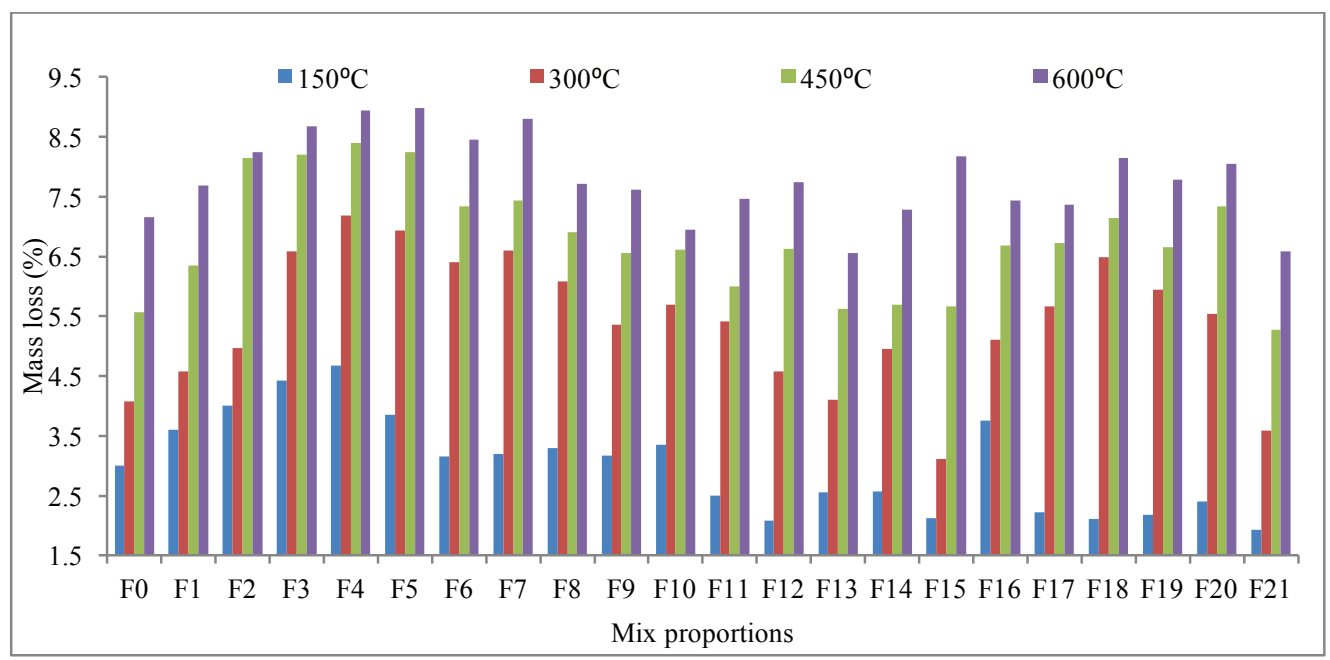

Figure 2. (a) Mass loss of studied mixes at different temperature.

Respectively, in proportion to plain cement mortar. The inclusion of SSP enhanced the mass loss from $20 \%$ to $55 \%, 10 \%$ to $64 \%, 14 \%$ to $51 \%$, and $7 \%$ to $25 \%$ at $150^{\circ} \mathrm{C}, 300^{\circ} \mathrm{C}, 450^{\circ} \mathrm{C}$, and $600^{\circ} \mathrm{C}$, respectively, with reference to plain mortar. The increment in mass loss due to TEA varied from $5 \%$ to $28 \%, 48 \%$ to $60 \%, 31 \%$ to $48 \%$, and $18 \%$ to $25 \%$ at $150^{\circ} \mathrm{C}, 300^{\circ} \mathrm{C}, 450^{\circ} \mathrm{C}$, and $600^{\circ} \mathrm{C}$ temperatures, respectively, with respect to mortar without any additives, i.e., F0. The reduction in mass loss for the combination of accelerators and SSP varied from $14 \%$ to $36 \%$, except for mixes $\mathrm{F} 10$ and $\mathrm{F} 16$ at $150^{\circ} \mathrm{C}$ temperature. For mixes $\mathrm{F} 10$ and $\mathrm{F} 16$, mass loss increased by $11 \%$ and $25 \%$ in comparison to control mix at $150^{\circ} \mathrm{C}$ temperature. The mass loss reduced by $10 \%, 5 \%$, and $8 \%$ at $300^{\circ} \mathrm{C}, 450^{\circ} \mathrm{C}$, and $600^{\circ} \mathrm{C}$, respectively, for mix proportion $\mathrm{F} 21$. The mix consisting of combination of accelerators and SSP increased the mass loss, and this increase in loss varied from $0.5 \%$ to $37.13 \%$ except for $\mathrm{F} 15$ at $300^{\circ} \mathrm{C}, 1 \%$ to $28 \%$ at $450^{\circ} \mathrm{C}$, and $3 \%$ to $14 \%$ at $600^{\circ} \mathrm{C}$, respectively, as shown in Figure $2(\mathrm{~b})$.

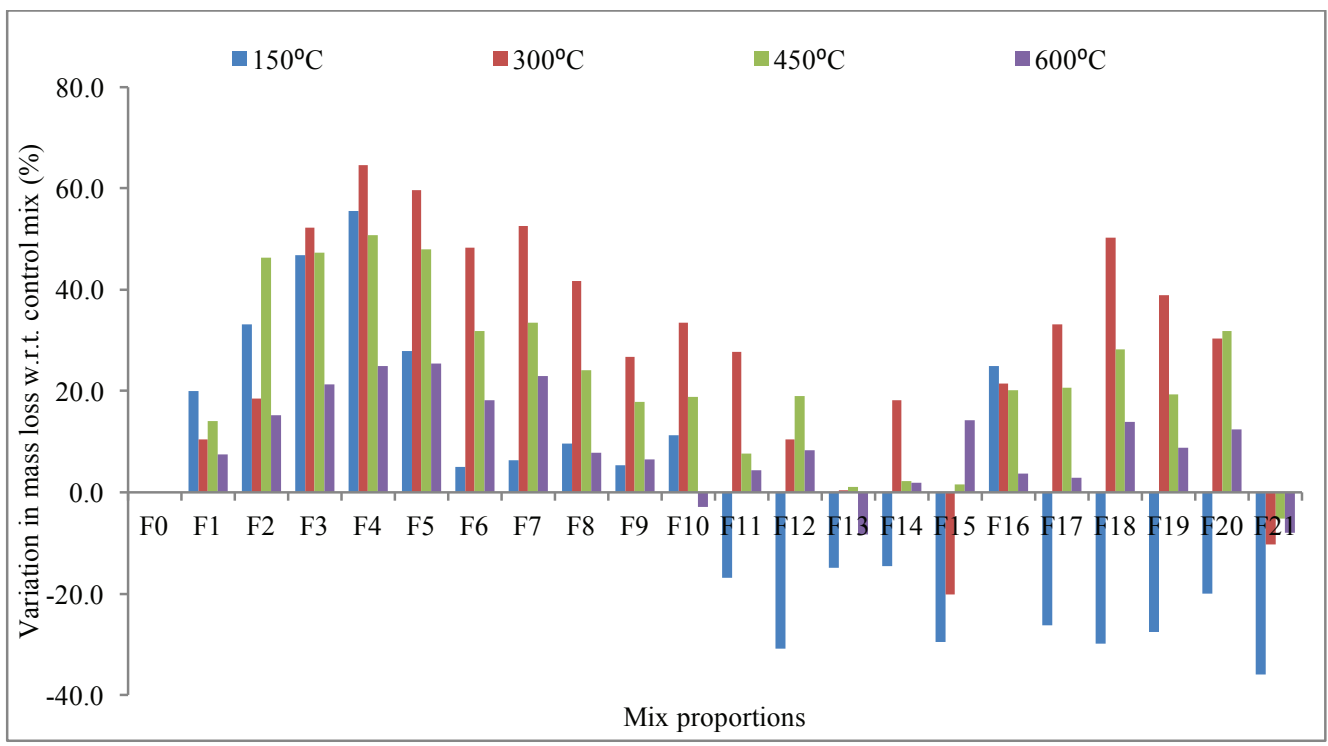

Figure 2. (b) Percentage variation of mass loss w.r.t. control mix at different temperatures. 


\section{Change in Strength}

The influence of SSP, CN, and TEA individually and in combination on cement mortar subjected to different temperatures, i.e., room temperature, $150^{\circ} \mathrm{C}, 300^{\circ} \mathrm{C}, 450^{\circ} \mathrm{C}$, and $600^{\circ} \mathrm{C}$, has been studied and shown in Figures 3 (a), (b), and (c). For mixes F1, F2, F3, F4, F12, F13, F14, and F16, residual strength increased up to a temperature of $450^{\circ} \mathrm{C}$ and then decreased at $600^{\circ} \mathrm{C}$, while the residual strength increased up to $300^{\circ} \mathrm{C}$; afterwards, the strength reduced with temperature for the rest of mixes. An increase in residual strength up to a certain temperature may be attributed to closer configuration of cement paste after water vaporization (Aydın 2008). The increase in strength was due to expansion of moisture molecules that separate the C-S-H (calcium-silicate-hydrate) layer due to the increase in temperature and weaken Vander Waal's physical forces within the cement composites. The moisture evaporation and reduction of distance between C-S-H gel layers result in enhancement in strength (Cheyrezy et al., 2001). The increase in strength may be due to acceleration of hydration process, while reduction was because of decomposition of cement paste (Khan and Abbas 2016). The reduction in strength after a certain temperature was because of degradation of C-S-H gel (Koksal et al., 2015). A sudden drop in residual strength was observed after saturation/threshold temperature, and this may be attributed to loss of water, which reduced calcium hydroxide content and formation of micro-cracks (Demirel and Kelestemur 2010). The loss in strength beyond certain temperature may be because of physical, chemical, and hydrothermal changes due to elevated temperature (Khaliq and Taimur 2018). Pachta et al. (2018) observed that the highest residual strength at $400^{\circ} \mathrm{C}$ temperature after strength decreased gradually, but it was high at $600^{\circ} \mathrm{C}$ temperature of lime-based mortar. The increase in strength may be due to the reaction that takes place as temperature increased, assisting the steam or liquid circulation due to porous structure, as reported by Pacthta et al. (2018). The residual strength of calcined clay limestone cement paste increased with the increase in temperature up to $300^{\circ} \mathrm{C}$ due to internal claving effect. The increase in residual strength may be because high temperature and high pressure promoted the unhydrated binder particles to continue to react because of internal claving effect. The strength improvement at higher temperature was generally associated with internal claving effect, as a result of flow of stream produced due to elimination of capillary, adsorbed, and chemically bound water in matrix at high temperature. The autoclave environment enables transport of moisture, so that further hydration of unhydrated cement becomes feasible (Llin et al., 2020). The variation in results may also be due to different exposure temperature, heating duration, curing condition, and nature of specimens. The residual strength of various mixes of specimens varied from $30.17 \mathrm{MPa}$ to $45.69 \mathrm{MPa}, 36.27 \mathrm{MPa}$ to $51.08 \mathrm{MPa}, 40.86 \mathrm{MPa}$ to 61.84 $\mathrm{MPa}, 41.16 \mathrm{MPa}$ to $65.54 \mathrm{MPa}$, and $30.94 \mathrm{MPa}$ to $54.73 \mathrm{MPa}$ at room temperature, $150^{\circ} \mathrm{C}, 300^{\circ} \mathrm{C}, 450^{\circ} \mathrm{C}$, and $600^{\circ} \mathrm{C}$, respectively.

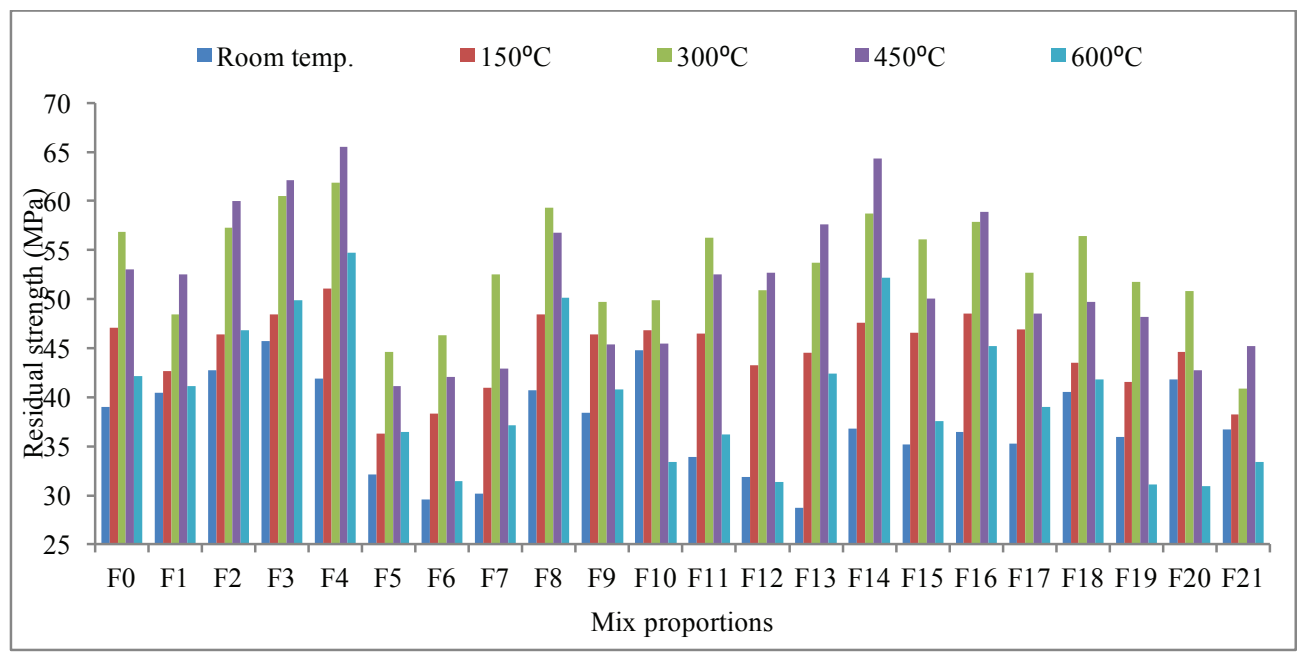

Figure 3. (a) Residual strength of various cement mortar mixes at different temperatures. 
Figure 3(a) illustrated that the residual strength of mortar enhanced up to a certain temperature and beyond that strength reduced with elevated temperature. Figure 3 (b) showed the percentage variation in the strength of distinct mixes of mortar at high temperatures with reference to control mix. The increase in strength of mortar consisting of $\mathrm{CN}, \mathrm{TEA}$, and SSP alone and in combination for all mixes varied from $3.7 \%$ to $17 \%, 1 \%$ to $8.6 \%, 1 \%$ to $8.7 \%, 7 \%$ to $23.5 \%$, and $0.6 \%$ to $30 \%$; and reduction varied from $1.6 \%$ to $26.3 \%, 1 \%$ to $23 \%, 1.4 \%$ to $28.2 \%, 1 \%$ to $22 \%$, and $1 \%$ to $26.7 \%$ at room temperature, $150^{\circ} \mathrm{C}, 300^{\circ} \mathrm{C}, 450^{\circ} \mathrm{C}$, and $600^{\circ} \mathrm{C}$ temperatures, respectively, with respect to $\mathrm{F} 0$ as shown in Figure 3 (b).

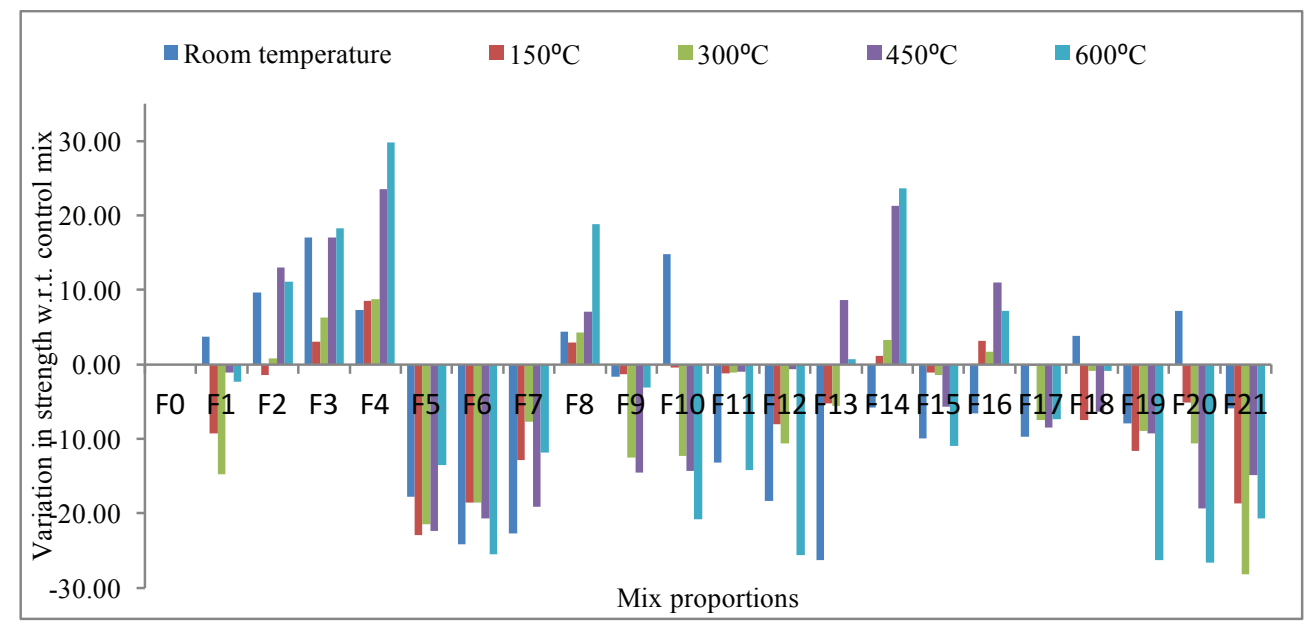

Figure 3. (b) Percentage variation of strength of mortar mixes at different temperatures w.r.t. control mix.

Figure 3(c) showed the percentage variation of strength of mortar at different temperatures with respect to the unheated specimens, i.e., room temperature. The increase in residual strength of cement mortar consisting of additives varied from $4 \%$ to $37 \%, 11 \%$ to $86 \%$, and $2 \%$ to $100 \%$ at $150^{\circ} \mathrm{C}, 300^{\circ} \mathrm{C}$, and $450^{\circ} \mathrm{C}$ temperatures for all mixes in proportion to room temperature. At $600^{\circ} \mathrm{C}$ temperature, the strength was lower than control mix for mixes F10, F12, F19, F20, and F21, as shown in Figure 3(c).

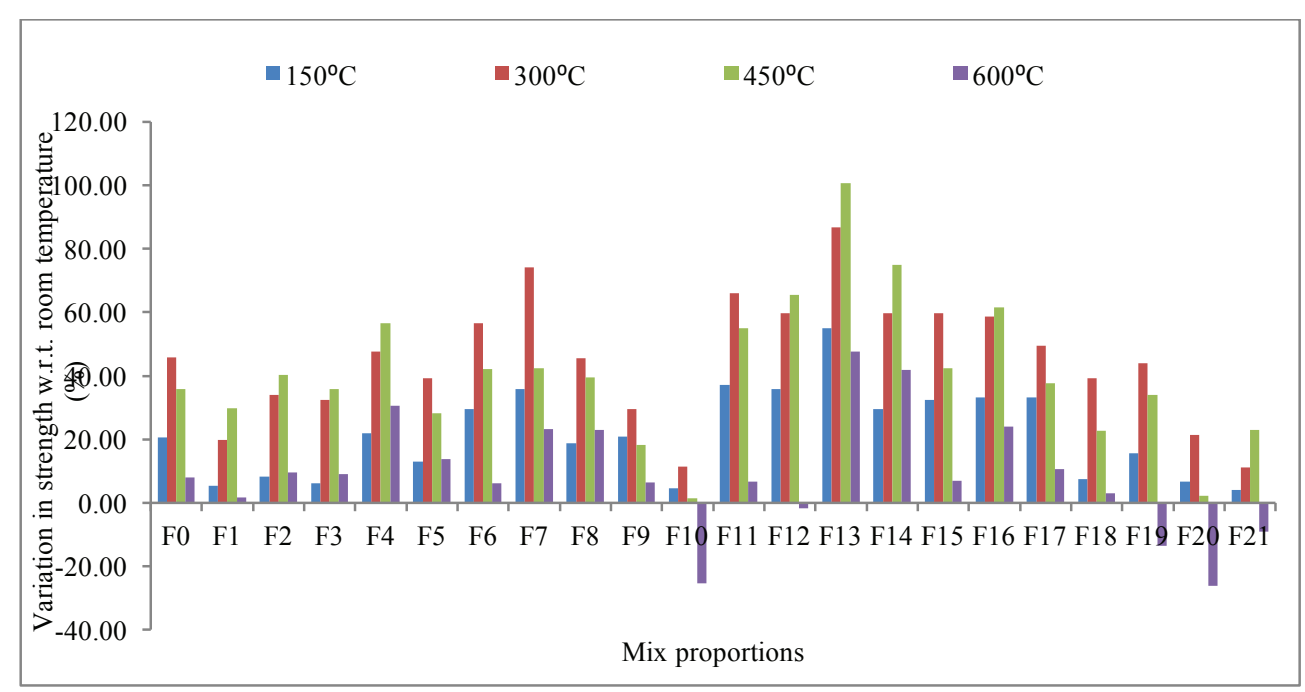

Figure 3. (c) Percentage variation of strength of mortar mixes at various temperature w.r.t. room temperature. 


\section{Ecological and Economical Analysis of Mortar}

In the present study, the influence of $\mathrm{CN}$, TEA, and $\mathrm{SSP}$ on the $\mathrm{EE}, \mathrm{ECO}_{2}$, and cost of mortar specimens with different mix proportions has been evaluated and is given in table 4. $\mathrm{EE}, \mathrm{ECO}_{2}$, and cost of mortar per unit strength at 28 days were also evaluated. The values of $\mathrm{EE}, \mathrm{ECO}_{2}$, and cost varied from 2724.37 to $2932.92 \mathrm{MJ} / \mathrm{m}^{3}, 503.57$ to $549.21 \mathrm{kgCO}_{2} \mathrm{e} / \mathrm{m}^{3}$, and 67 to $141 \mathrm{USD} / \mathrm{m}^{3}$ for all the mix proportions of mortar. It has been observed from table 4 that the use of $\mathrm{EE}, \mathrm{ECO}_{2}$, and cost reduced with the use of SSP. The addition of CN slightly increased the ecological impact on the environment. Since the quantity of TEA was very little, therefore, its effects on these factors are negligible. The percentage variation in $\mathrm{EE}, \mathrm{ECO}_{2}$, and cost with or without unit strength has been illustrated in Figure 4.

Table 4. Ecological and economic analysis of mortar.

\begin{tabular}{|c|c|c|c|c|c|c|}
\hline Mix No. & $\mathrm{EE}\left(\mathrm{MJ} / \mathrm{m}^{3}\right)$ & $\begin{array}{c}\mathrm{ECO}_{2} \\
\left(\mathrm{~kg} \mathrm{CO}_{2} \mathrm{e} / \mathrm{m}^{3}\right)\end{array}$ & $\begin{array}{c}\text { Cost } \\
\left(\mathrm{USD} / \mathrm{m}^{3}\right)\end{array}$ & $\begin{array}{l}\text { EE/28 } \\
\text { D-CS }\end{array}$ & $\begin{array}{c}\mathrm{ECO}_{2} / 28 \\
\mathrm{D}-\mathrm{CS}\end{array}$ & $\begin{array}{c}\text { Cost } / 28 \\
\text { D-CS }\end{array}$ \\
\hline F0 & 2931.35 & 543.67 & 71 & 75.09 & 13.93 & 1.8 \\
\hline F1 & 2862.32 & 530.3 & 70 & 71.1 & 13.17 & 1.7 \\
\hline F2 & 2793.35 & 516.94 & 69 & 65.28 & 12.08 & 1.6 \\
\hline F3 & 2724.37 & 503.57 & 68 & 59.63 & 11.02 & 1.5 \\
\hline F4 & 2655.35 & 490.2 & 67 & 60.69 & 11.2 & 1.5 \\
\hline F5 & 2931.35 & 543.67 & 73 & 91.32 & 16.94 & 2.3 \\
\hline F6 & 2931.35 & 543.67 & 75 & 99.03 & 18.37 & 2.5 \\
\hline F7 & 2931.35 & 543.67 & 79 & 96.84 & 17.96 & 2.6 \\
\hline F8 & 2932.13 & 546.44 & 105 & 73.78 & 13.75 & 2.6 \\
\hline F9 & 2932.92 & 549.21 & 139 & 78.42 & 14.68 & 3.7 \\
\hline F10 & 2932.13 & 546.44 & 107 & 91.97 & 17.14 & 3.4 \\
\hline F11 & 2932.92 & 549.21 & 141 & 101.98 & 19.1 & 4.9 \\
\hline F12 & 2793.35 & 516.94 & 73 & 82.42 & 15.25 & 2.2 \\
\hline F13 & 2724.37 & 503.57 & 76 & 60.83 & 11.24 & 1.7 \\
\hline F14 & 2794.13 & 519.7 & 103 & 78.14 & 14.53 & 2.9 \\
\hline F15 & 2725.16 & 506.34 & 102 & 77.09 & 14.32 & 2.9 \\
\hline F16 & 2794.92 & 522.47 & 137 & 76.64 & 14.33 & 3.8 \\
\hline F17 & 2725.94 & 509.1 & 136 & 77.31 & 14.44 & 3.9 \\
\hline F18 & 2794.13 & 519.7 & 111 & 69.77 & 12.98 & 2.8 \\
\hline F19 & 2725.16 & 506.34 & 110 & 75.38 & 14.01 & 3.1 \\
\hline F20 & 2794.92 & 522.47 & 141 & 70.9 & 13.25 & 3.6 \\
\hline F21 & 2725.94 & 509.1 & 140 & 71.83 & 13.42 & 3.7 \\
\hline
\end{tabular}




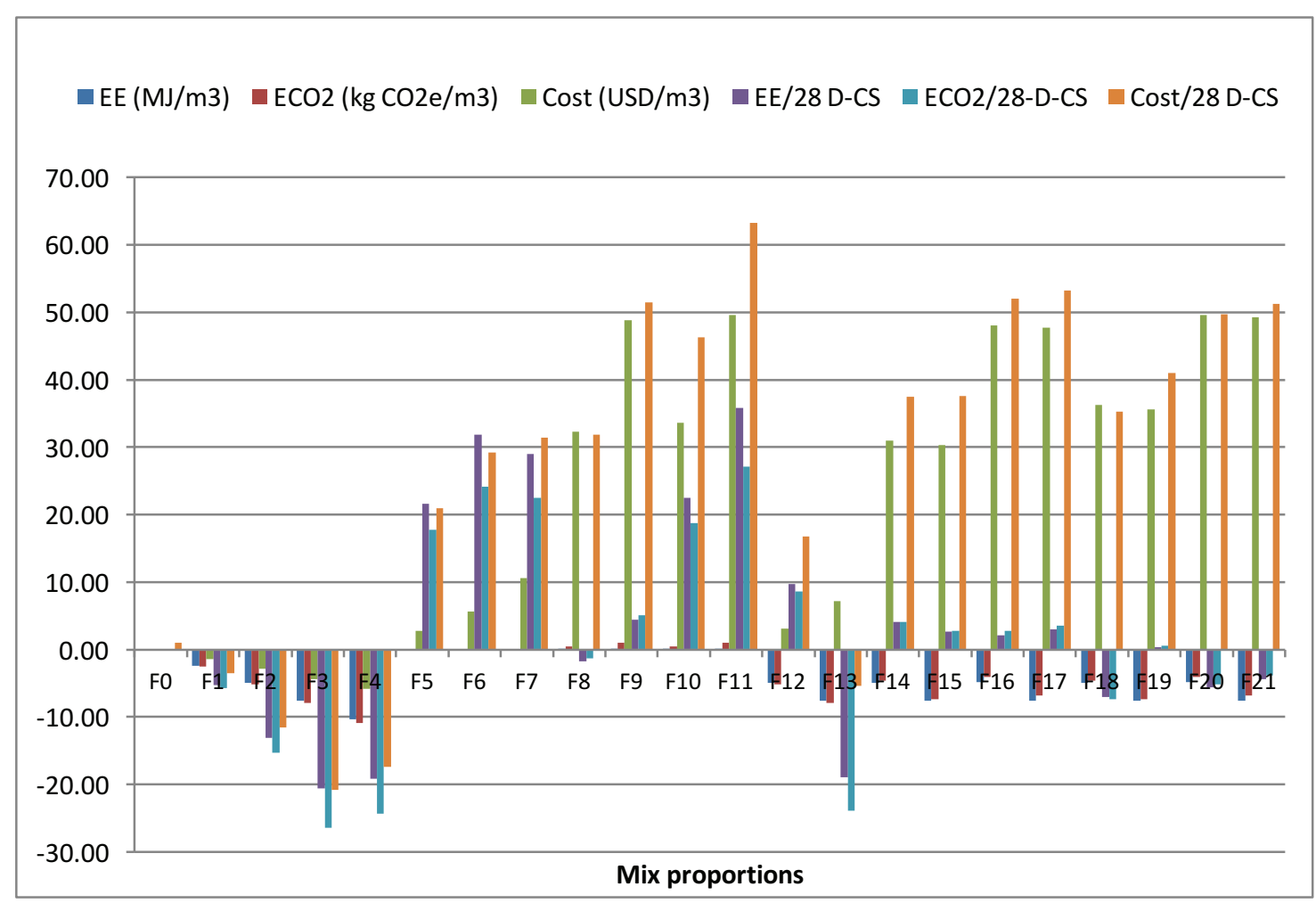

Figure 4. Percentage variation in ecological and economic parameter.

The values of EE/28D-CS, ECO $2 / 28 \mathrm{D}-\mathrm{CS}$, and cost/28D-CS varied from 59.63 to $102,11.02$ to 19.01 , and 108.72 to 357 for all the mix proportions. Figure 4 depicted that the inclusion of SSP in mortar reduced the energy consumption, emission of $\mathrm{CO}_{2}$, and cost of mortar per unit strength. Therefore, the exercise of SSP in mortar required less energy, low emission of $\mathrm{CO}_{2}$, and low cost for the unit strength, whereas the addition of chemical admixtures required high energy, more emission of $\mathrm{CO}_{2}$, and high cost for the unit strength of mortar.

\section{Performance index}

The performance index of mortar of different mix proportions was evaluated and has been given in table 5. The performance of mortar of plain mix was taken as 1.0. The values greater than 1.0 taken as superior performance and lower value indicate the poor performance with reference to control mix. The mixes F3 and F13 have the superior and interior performance of mortar specimens compared to plain mix at room temperature. Similarly, the mix F4 had the superior performance among all the mix performances at all temperatures. 
Table 5. Performance index of different mixes of mortar.

\begin{tabular}{|c|c|c|c|c|c|}
\hline Mix No. & Room temp. & $150^{\circ} \mathrm{C}$ & $300^{\circ} \mathrm{C}$ & $450^{\circ} \mathrm{C}$ & $600^{\circ} \mathrm{C}$ \\
\hline F0 & 1.00 & 1.00 & 1.00 & 1.00 & 1.00 \\
\hline F1 & 1.04 & 0.91 & 0.85 & 0.99 & 0.98 \\
\hline $\mathrm{F} 2$ & 1.10 & 0.99 & 1.01 & 1.13 & 1.11 \\
\hline F3 & 1.17 & 1.03 & 1.06 & 1.17 & 1.18 \\
\hline F4 & 1.07 & 1.09 & 1.09 & 1.24 & 1.30 \\
\hline F5 & 0.82 & 0.77 & 0.79 & 0.78 & 0.87 \\
\hline F6 & 0.76 & 0.81 & 0.81 & 0.79 & 0.74 \\
\hline F7 & 0.77 & 0.87 & 0.92 & 0.81 & 0.88 \\
\hline F8 & 1.04 & 1.03 & 1.04 & 1.07 & 1.19 \\
\hline F9 & 0.98 & 0.99 & 0.87 & 0.86 & 0.97 \\
\hline F10 & 1.15 & 1.00 & 0.88 & 0.86 & 0.79 \\
\hline F11 & 0.87 & 0.99 & 0.99 & 0.99 & 0.86 \\
\hline F12 & 0.82 & 0.92 & 0.89 & 0.99 & 0.74 \\
\hline F13 & 0.74 & 0.95 & 0.94 & 1.09 & 1.01 \\
\hline F14 & 0.94 & 1.01 & 1.03 & 1.21 & 1.24 \\
\hline F15 & 0.90 & 0.99 & 0.99 & 0.94 & 0.89 \\
\hline F16 & 0.93 & 1.03 & 1.02 & 1.11 & 1.07 \\
\hline F17 & 0.90 & 1.00 & 0.93 & 0.92 & 0.93 \\
\hline F18 & 1.04 & 0.93 & 0.99 & 0.94 & 0.99 \\
\hline F19 & 0.92 & 0.88 & 0.91 & 0.91 & 0.74 \\
\hline F20 & 1.07 & 0.95 & 0.89 & 0.81 & 0.73 \\
\hline $\mathrm{F} 21$ & 0.94 & 0.81 & 0.72 & 0.85 & 0.79 \\
\hline
\end{tabular}

\section{Micro-Structural Properties}

The microstructural properties of selected mix proportions were studied using SEM techniques at room temperature and $300^{\circ} \mathrm{C}$ temperature. SEM technique has been practiced to get the information about the morphology and crystalline structure of mortar specimens. It has been observed from Figure 5 (i-v) that C-S-H gel was spread over the matrix, which helped in strength enhancement. For mix proportions F8 and F14, dense and compact matrix was formed at all temperatures, and the presence of a lower amount of voids was observed for unheated specimens. 


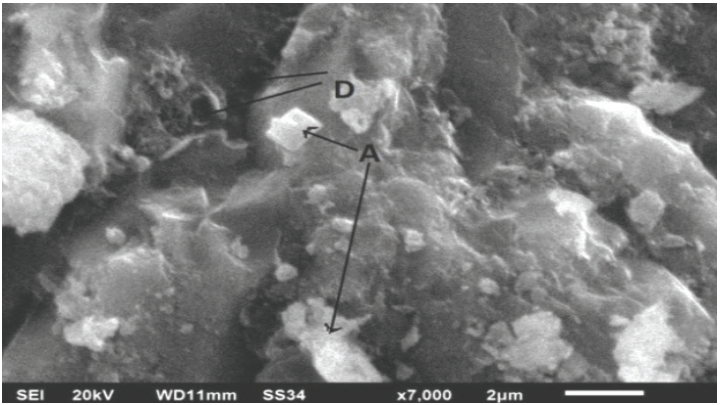

i (a)

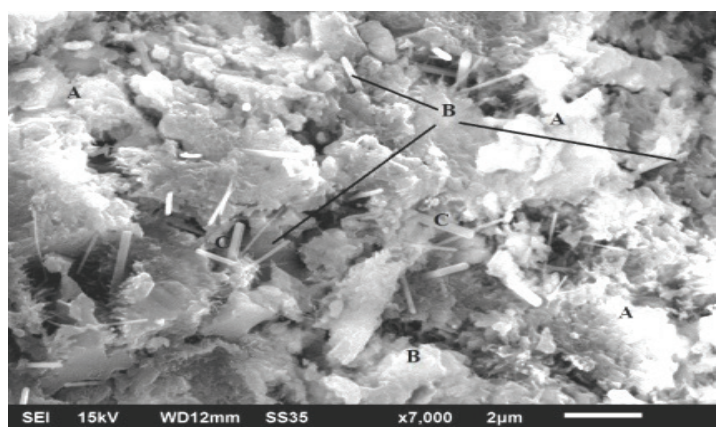

ii (b)

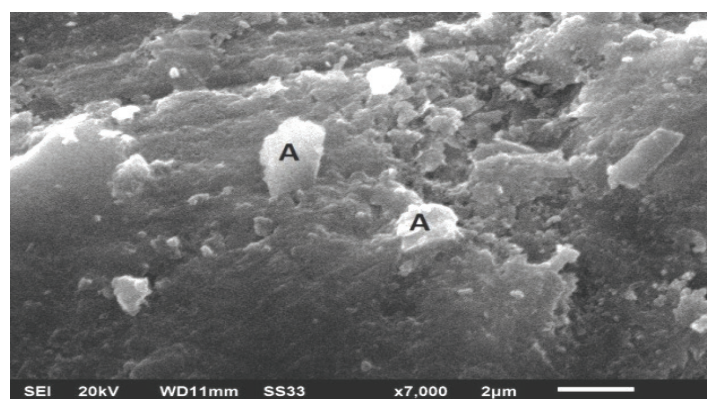

iii (a)

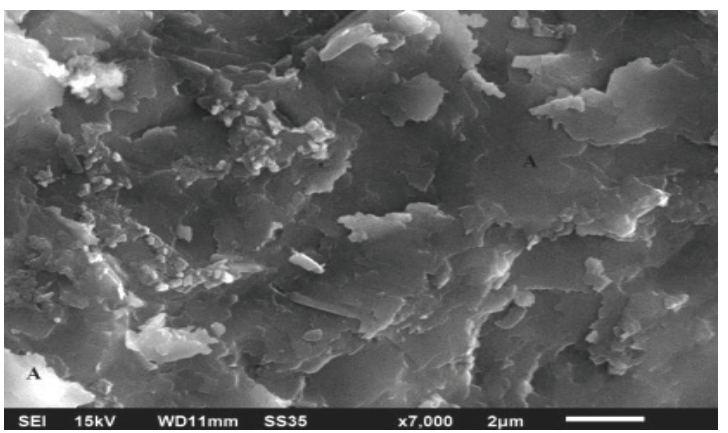

iv (a)

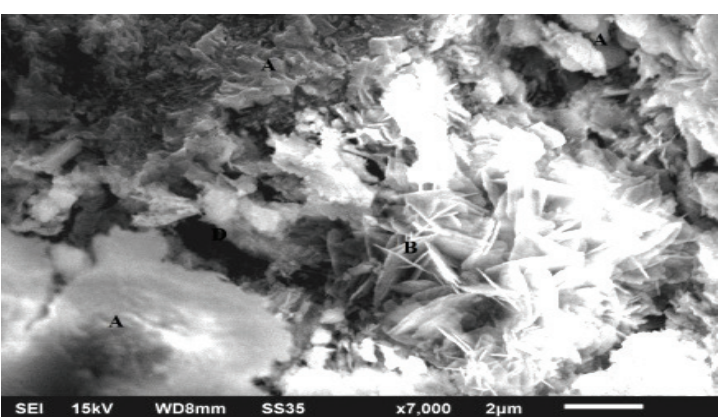

i (b)

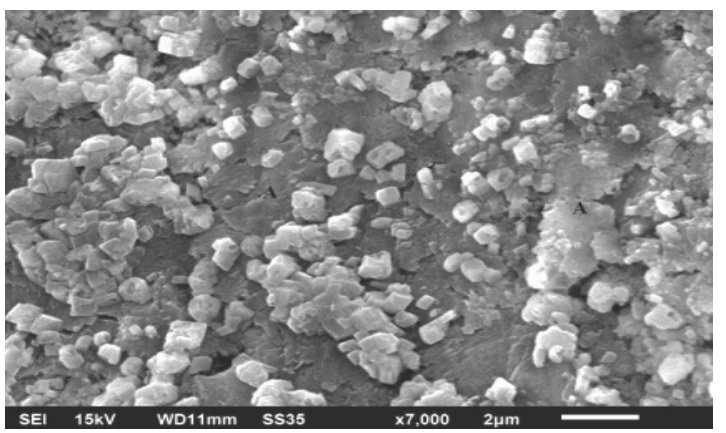

ii (b)

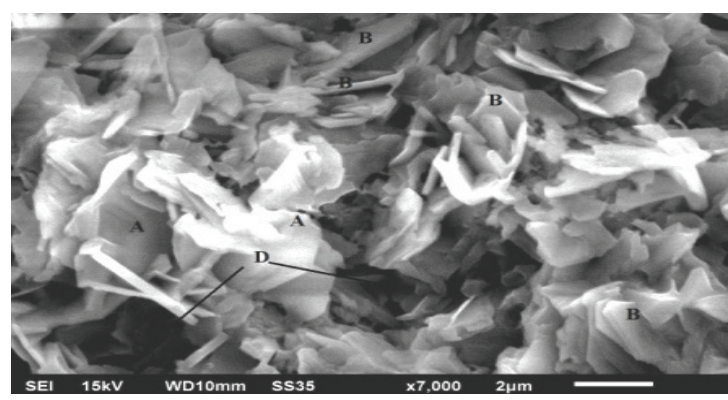

iii (b)

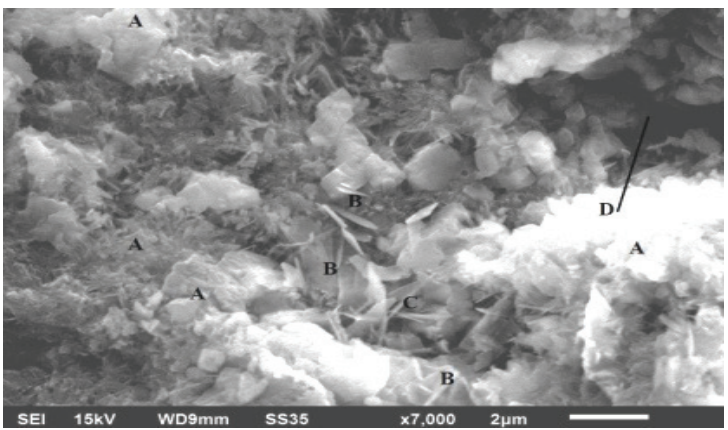

iv (b) 


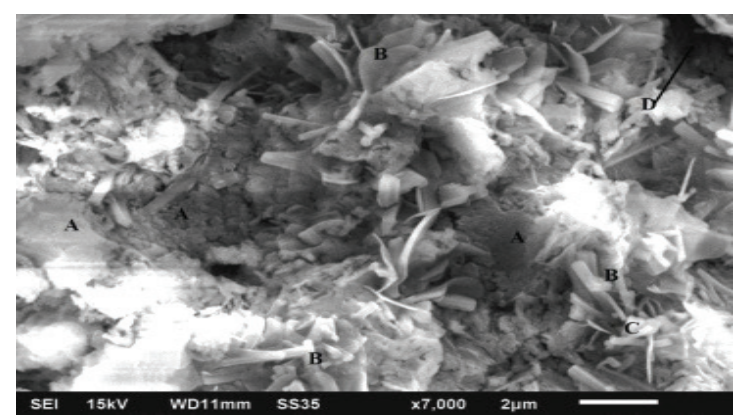

v (a)

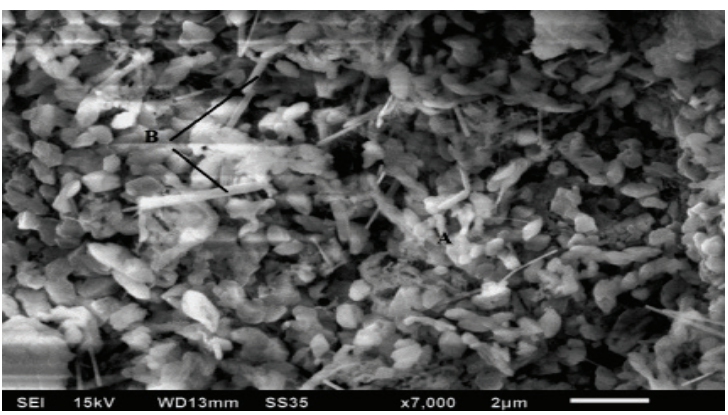

$\mathrm{v}(\mathrm{b})$

where $\mathrm{a}=$ specimens at room temperature, $\mathrm{b}=$ specimens at $300^{\circ} \mathrm{C}$ temperature and $* \mathrm{~A}=\mathrm{C}-\mathrm{S}-\mathrm{H}, \mathrm{B}=\mathrm{CH}$, $\mathrm{C}=$ ettringite and $\mathrm{D}=$ voids

Figure 5. SEM images of optimized mix proportions of (i) F0; (ii) F4; (iii) F8; (iv) F11 and (v) F16.

Compared to room temperature, specimens showed quite loose microstructure with pores and cracks. For F16 and F4 mixes, the presence of ettringite can be seen even at room temperature in comparison to a temperature at $300^{\circ} \mathrm{C}$. For mix F4, dense matrix was formed, and the presence of C-S-H gel can be seen as compared to other mixes. The presence of cracks can be seen in fig. $5 \mathrm{i}$ (b) at $300^{\circ} \mathrm{C}$ as compared to other mixes at the same temperature. At $300^{\circ} \mathrm{C}$ temperature, quite dense and compact microstructure was observed for mixes F4 and F11 as compared to that of mixes F8 and F16, and also visible pores were present for later mixes. Also, dense structure at room temperature is gradually destroyed and became loose. The denseness and fewer micropores may be due to steady dehydration. For mixes F4 and F16, some round shape structure is observed that dicalcium silicate may be formed by the decomposition of calcium silicate hydrate at high temperature, similar to what was reported by Lin et al. (2020).

\section{CONCLUSION}

Stone slurry powder and admixtures were used in cement mortar to examine the behavior of high temperature on the mass, residual strength, and microstructure properties of specimens with different mix proportions. The heating temperatures were kept at $150^{\circ} \mathrm{C}, 300^{\circ} \mathrm{C}, 450^{\circ} \mathrm{C}$, and $600^{\circ} \mathrm{C}$ for 60 minutes, and results were compared with the unheated sample. The following outcomes were found from the study:

- The mass loss of mortar consisting combination of accelerator and SSP decreased with the temperature due to the evaporation of free water. The reduction in mass loss varied from $1.93 \%$ to $4.68 \%, 3.59 \%$ to $7.18 \%, 5.28 \%$ to $8.4 \%$, and $6.59 \%$ to $8.94 \%$, respectively, at $150^{\circ} \mathrm{C}, 300^{\circ} \mathrm{C}, 450^{\circ} \mathrm{C}$, and $600^{\circ} \mathrm{C}$ temperatures for all the mix proportions.

- The residual strength of mortar specimens using calcium nitrate and triethanolamine increased with the rise in temperature up to $300^{\circ} \mathrm{C}$, which may be because of the acceleration of the hydration process; after that, strength decreased due to decomposition of CSH as seen in the SEM images. The residual strength of mortar with various mixes varied from $30.17 \mathrm{MPa}$ to $45.69 \mathrm{MPa}, 36.27 \mathrm{MPa}$ to $51.08 \mathrm{MPa}, 40.86$ $\mathrm{MPa}$ to $61.84 \mathrm{MPa}, 41.16 \mathrm{MPa}$ to $65.54 \mathrm{MPa}$, and $30.94 \mathrm{MPa}$ to $54.73 \mathrm{MPa}$ at room temperature, $150^{\circ} \mathrm{C}$, $300^{\circ} \mathrm{C}, 450^{\circ} \mathrm{C}$, and $600^{\circ} \mathrm{C}$, respectively.

- Use of SSP increased residual strength of mortar specimens up to $450^{\circ} \mathrm{C}$ due to internal claving effect; beyond this, it decreased the strength due to reduction of $\mathrm{CH}$ content, alteration of morphology, and formation of micro-cracks as observed from the SEM-EDS analysis. 
- $\mathrm{CN}(1 \%)$ at $300^{\circ} \mathrm{C}$ and $\mathrm{SSP}(7.5 \%$ and $10 \%)$ at $450^{\circ} \mathrm{C}$ gave satisfactory performance under elevated temperature in comparison to all the mix proportions.

- The microstructure of mortar specimens altered under the exposure to elevated temperatures. As observed from SEM-EDS analysis, at $300^{\circ} \mathrm{C}$ temperature, dense and compact microstructure was formed, C-S-H gel was spread over the matrix, and little amount of ettringite formation was seen in comparison to specimens at room temperature.

- $\quad$ The mixes F3 (7.5\% SSP), F4 (10\% SSP), F8 (1\% CN), F14 ( $2 \% \mathrm{CN}+5 \% \mathrm{SSP})$, and F16 (2\% CN + $5 \% \mathrm{SSP})$ were found to have better performance and can be used when exposing temperature rose to $450^{\circ} \mathrm{C}$.

- The incorporation of SSP in mortar reduced the $\mathrm{EE}, \mathrm{ECO}_{2}$, and cost among all the additives. The addition of chemical admixtures hiked the cost of mortar construction.

- The performance evaluation of different mix proportions was also evaluated with reference to plain mix.

The effect of elevated temperature $\left(150^{\circ} \mathrm{C}, 300^{\circ} \mathrm{C}, 450^{\circ} \mathrm{C}\right.$, and $\left.600^{\circ} \mathrm{C}\right)$ on mortar mix consisting of accelerators and SSP was studied for change in mass, strength, and microstructural properties compared with specimens at room temperature. The stone with stone slurry powder and calcium nitrate had better performance at elevated temperature than other mix proportions. $\mathrm{CN}$ and SSP in mortar can be used when temperatures rise to $300^{\circ} \mathrm{C}$ and $450^{\circ} \mathrm{C}$, respectively.

\section{ACKNOWLEDGMENT}

The authors wish to thank the Ministry of Human Resources and Development, Government of India, for the financial support.

\section{REFERENCES}

Aggoun, S., Cheikh-Zouaoui, M., Chikh, N.\& Duval, R. 2008. Effect of some admixtures on the setting time and strength evolution of cement paste at early ages. Construction and Building Materials 22: 106-110.

Arioz, O. 2007. Effects of elevated temperatures on properties of concrete. Fire Safety Journal 42: 516-522.

Aslani, F.\& Samali, B. 2014. constitutive relationships for steel fibre reinforced concrete at elevated temperatures. Fire Technology 40: 1249-1268.

Aydın, S. 2008. Development of a high-temperature-resistant mortar by using slag and pumice. Fire Safety Journal 43: 610-617.

Baloch, W.L., Khushnood, R.A., Memon, S.A., Ahmed, W.\& Ahmad, S. 2018. Effect of elevated temperatures on mechanical performance of normal and lightweight concretes reinforced with carbon nanotubes. Fire Technology 54: 1331-1367.

Belouadah, M., Rahmouni, Z.E.A.\& Tebbal, N. 2018. Effects of glass powder on the characteristics of concrete subjected to high temperatures. Advances in Concrete Construction 6: 311-322.

Bing”ol, A.F.\& G"ul, R. 2009. Effect of elevated temperatures and cooling regimes on normal strength concrete. Fire Material 33: 79-88.

Bodnarova, L., Hroudova, J., Brozovsky, J., Zach, J.\& Valek, J. 2017. Behaviour of cement composites with lightweight and heavyweight aggregates at high temperatures. Periodica Polytechnica Civil Engineering 61: $272-281$.

Cheyrezy, M., Khoury, G.\& Behloul, M. 2001. Mechanical properties of four high-performance concretes in compression at high temperatures. Revue Française de Génie Civil 5: 1159-1180. 
Demirel, B.\& Kelestemur, O. 2010. Effect of elevated temperature on the mechanical properties of concrete produced with finely ground pumice and silica fume. Fire Safety Journal 45: 385-391.

Devi K, Saini B.\& Aggarwal P. 2020. Long term performance of concrete using additives. International Journal of Microstructure and Materials Properties. https://doi.org/10.1504/IJMMP.2020.104612

Devi, K., Acharya, K.G.\& Saini, B. 2018b. Significance of stone slurry powder in normal and high strength concrete. In: Singh, H., Garg P., Kaur I. (Eds.). Sustainable Waste Management through Design. ICSWMD 2018. pp. 484-492. Springer Nature Switzerland AG.

Devi, K., Saini, B.\& Aggarwal, P. 2019. Utilization of Kota stone slurry powder and accelerators in concrete. Computers and Concrete 23: 189-201.

Devi, K., Saini, B.\& Aggarwal, P. 2018a. Effect of accelerators with waste material on the properties of cement paste and mortar. Computers and Concrete 22: 153-159.

Ezziane, M., Molez, L., Jauberthie, R.\& Rangeard, D. 2011. Heat exposure tests on various types of fibre mortar. European Journal of Environmental and Civil Engineering 15: 715-726.

Flower D.J.M.\& Sanjayan J.G. 2007. Green house gas emissions due to concrete manufacture. The International Journal of Life Cycle Assessment 12:282. https://doi.org/10.1065/lca2007.05.327

Güçlüer, K. 2021. An investigation of the effect of different aggregate types on concrete properties with thin section and nondestructive methods. Journal of Engg. Research 12:15-24

Guerrieri, M., Sanjayan, J.\& Collins, F. 2009. Residual compressive behavior of alkali-activated concrete exposed to elevated temperatures. Fire and Materials 33: 51-62.

Gupta T., Kothari S., Siddique S., Sharma R.K.\& Chaudhary S. 2019. Influence of stone processing dust on mechanical, durability and sustainability of concrete. Construction and Building Materials 223: 918-927.

Hager, I., Tracz, T., Śliwiński, J.\& Krzemień, K. 2016. The influence of aggregate type on the physical and mechanical properties of high-performance concrete subjected to high temperature. Fire and Materials 40: $668-682$.

IS 383 (2016), Indian Standard Specification for coarse and fine aggregates from natural sources for concrete, Bureau of Indian Standard; New Delhi, India.

IS 4031 (Part 6) (1988), Indian Standard Methods of physical tests for hydraulic cement - determination of compressive strength of hydraulic cement other than masonry cement, Bureau of Indian Standard; New Delhi, India.

IS 8112 (1989), Specification for 43-grade ordinary portland cement, Bureau of Indian Standard; New Delhi, India.

Karahan, O. 2011. Residual compressive strength of fire-damaged mortar after post-fire-air-curing. Fire and Materials 35: 561-567.

Kayali O.\& Ahmed M.S. 2013. Assessment of high volume replacement fly ash concrete -Concept of performance index. Construction and Building Materials 39: 71-76.

Khaliq, W.\& Taimur. 2018. Mechanical and physical response of recycled aggregates high-strength concrete at elevated temperatures. Fire Safety Journal 96: .203-214.

Khan, M.S.\& Abbas, H. 2016. Performance of concrete subjected to elevated temperature. European Journal of Environmental and Civil Engineering 20: 532-543.

Koksal, F., Gencel, O.\& Kaya, M. 2015. Combined effect of silica fume and expanded vermiculite on properties of lightweight mortars at ambient and elevated temperatures. Construction and Building Materials 88: 175187. 
Kumar, N.V.S.\& Ram, K.S.S. 2019. Performance of concrete at elevated temperatures made with crushed rock dust as filler material. Materials Today: Proceedings 18: 2270-2278.

Lin, R., Han, Y.\& Wang, X. 2020. Macro-meso-micro experimental studies of calcined clay limestone cement $\left(\mathrm{LC}^{3}\right)$ paste subjected to elevated temperature. Cement and concrete composites. DOI: https://doi.org/10.1016/j.cemconcomp.2020.103871

Long, W., Gu, Y., Liao, J.\& Xing, F. 2017. Sustainable design and ecological evaluation of low binder selfcompacting concrete. Journal of Cleaner Production 167: 317-325.

Mohammed, M.K., Dawson, A.R.\& Thom, N.H. 2013. Production, microstructure and hydration of sustainable self compacting concrete with different types of filler. Construction and Building Materials 49: 84-92.

Nadeem, A., Memon, S.A.\& Lo, T.Y. 2013. Mechanical performance, durability, qualitative and quantitative analysis of microstructure of fly ash and metakaolin mortar at elevated temperatures. Construction and Building Materials 38: 338-347.

Netinger, I., Kesegic, I.\& Guljas, I. 2011. The effect of high temperatures on the mechanical properties of concrete made with different types of aggregates. Fire Safety Journal 46: 425-430.

Peng, G. F., Jiang, Y. C., Li, B. H., Zhang, J.\& Shi, Y. X. 2014. Effect of high temperature on normal-strength high-performance concrete. Material Research Innovations 18: 290-293.

Rana, A., Kalla, P.\& Csetenyi, L.J. 2015. Sustainable use of marble slurry in concrete. Journal of Cleaner Production 94: 304-311.

Sánchez, M.A., Molina, W.M., García, H.L.C., Guzmán, E.M.A., Acosta, A.A.T.\& Ortega, J.M.P. 2018. Properties of Portland Cement Mortar with Substitutions of Natural and Expanded Perlite. Periodica Polytechnica Civil Engineering 62: 508-516.

Sarıdemir, M., Çelikten, S.\& Yıldırım, A. 2020. Mechanical and microstructural properties of calcined diatomite powder modified high strength mortars at ambient and high temperatures. Advanced Powder Technology. https://doi.org/10.1016/j.apt.2020.05.024

Shah, K.W.\& Huseien, G.F. 2020. Bond strength performance of ceramic, fly ash and GBFS ternary wastes combined alkali-activated mortars exposed to aggressive environments. Construction and Building Materials 251: 119088. https://doi.org/10.1016/j.conbuildmat.2020.119088

Shaikh, F.U.A.\& and Taweel, M. 2015. Compressive strength and failure behaviour of fibre reinforced concrete at elevated temperatures. Advances in Concrete Construction 3: 283-293.

Siddique, S., Chaudhary, S., Shrivastava, S.\& Gupta, T. 2019. Sustainable utilisation of ceramic waste in concrete: Exposure to adverse conditions. Journal of Cleaner Production 210: 246-255.

Singh, M., Srivastava, A.\& Bhunia, D. 2017. An investigation on effect of partial replacement of cement by waste marble slurry. Construction and Building Materials 134: 471-488.

T“urkmen, I.\& Fındık, S.B. 2013. Several properties of mineral admixture lightweight mortars at elevated temperatures. Fire and Materials 37: 337-349.

Thaarrini, J.\& Ramasamy, V. 2016. Properties of foundry sand, ground granulated blast furnace slag and bottom ash based geopolymers under ambient conditions. Periodica Polytechnica Civil Engineering 60: 159-168.

Wang, Y.H., Xu, Y.D.\& He, Z.H. 2015. Effect of limestone powder on creep of high strength concrete. Material Research Innovations 19: 220-223.

Xin, J., Zhang, G., Liu, Y., Wang Z., Wu, Z. 2018. Numerical analysis of effect of temperature history and restraint degree on cracking behavior of early-age concrete. Journal of Engineering Research 8:24-43. 